\title{
ホドグラフ法による合流部流線の解析 \\ ANALYSIS OF STREAMLINES AT A CONFLUENCE BY THE HODOGRAPH METHOD
}

\author{
藤 田一郎*・河 村三 郎** \\ By Ichiro FUJITA and Saburo KOMURA
}

\begin{abstract}
At a confluence, a separated shear layer accompanying a recirculating region is formed, which decreases the efficiency of the flow. In this study, the hodograph method is applied to the flow at a confluence to make clear the characteristics of separated streamlines. A free streamline and a boundary streamline which represents the center of a separated shear layer and the boundary between the combined flows respectively, are calculated for arbitrary confluence angles and channel width ratios. Also, a shape factor of a recirculating region is theoretically obtained with a reasonable agreement with the experimental results.
\end{abstract}

Keywords: confluence, hodograph method, junction flow, free streamline, conformal mapping

\section{1. まえがき}

開水路合流部の流れは, 開水路流れにおいて最も複雑 な流況を呈する流れの 1 つであり, その流れの機構の解 明は河川工学上非常に重要な課題である.しかしながら, 一様流や湾曲部流れ，あるいは複断面流れのような他の 開水路流れにおける研究の進展に比べると，十分な検討 がなされているとはいえず，いわば開水路流れを総合的 に解明するうえでの未開拓分野であると思われる。もち ろん,これまでにも合流部についての流れの検討は行わ れてきており，運動量，あるいはエネルギーの定理を用 いた解析的研究 ${ }^{1) ~ 6)}$, 数值解析手法を用いた研究 ${ }^{7) ~ 10)}$, 移動床合流部での局所洗掘，あるいは河床変動に関する

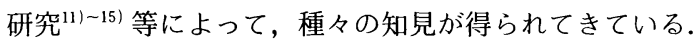
しかしながら，合流部の流れで特に特徴的な死水域につ いては，実験的な検討が行われているものの，理論的に は十分な検討がなされているとはいいがたい，死水域の 形成は河川工学的な立場からみれば，流水の有効断面を 減少させ，洪水の疎通能力を低下させるという点で問題 であり，その意味で特に死水域幅に関するその特性の解

* 正会員 工修 岐阜大学講師 工業短期大学部土木工学科 （开501-11 岐皁市柳戸1-1）

** 正会員 工博 岐阜大学教授 工学部土木工学科 (同上)
明は非常に重要と考えられる。

死水域は合流点で生じる剝離せん断層の一部が側壁に 再付着して形成される閉じた渦領域であり, 剝離泡とい うこともできる. 死水域がほぼ最大幅に至るまでの領域 における剝離せん断層は, 厚さが非常に薄く一本の自由 流線とみなせると考えられる。 それより下流の流れに対 しては, 自由流線は剥離せん断層の時間平均的な中心に 対応するものと考えられる ${ }^{16)}$. 本研究では問題を単純化 するために，合流部の流れを自由流線を用いて表わし， ホドグラフ法により流線の解析を行う。ホドグラフ法に よる解析はポテンシャル流を仮定してはいるが，平面壁 上の突起部からの剥離流線に関しては実験值とも良好な 一致を示すことが知られている ${ }^{17)}$. 合流部の流れは, 実 際には三次元的な特性を有していると考えられるが，レ イノルズ数の大きい開水路流れにおける水深平均的な流 れを対象とするならば，二次元モデルであるホドグラフ 法は十分に有効と考えられる.

ホドグラフ法を合流部に適用した例としては, Webber $ら^{18)}$, 池田ら ${ }^{19)}$, Modi ら ${ }^{20)}$ ，および著書ら ${ }^{21)}$ の研究 があるが, Webber ら, 池田らの解析は合流角が 90 度 に固定されており一般性に欠けている. Modi らの解析 結果については Best ら ${ }^{22)}$ が指摘しているように，実験 值との適合性が非常に悪い。この不適合性は，合流する 
$2 つ$ つ流れの境界の流線を無視するなど解析手法自体に 問題があったためと思われる.

以上のような点に鑑み，本研究ではホドグラフ法を正 確に合流部に適用することにより，本手法の有効性につ いて検討することとした。この手法は理論としては古典 的であるが，自由流線についての解析解が比較的簡単に 得られる点で重要である。また，一般にホドグラフ法で は自由流線のみを解析の対象としているが，本研究では 水路内部の流線も考慮し, 実験值との比較から，本理論 の適用限界についても検討している.

\section{2. ホドグラフ法の概要}

本研究では対数速度を用いてホドグラフ $\Omega$ を次のよ うに定義する.

$\Omega=\ln \left(V_{3} \cdot d z / d W\right)$

ここに, $z$ : 物理面の座標 $(=x+i y), W$ : 複素速度 ポテンシャル $(=\phi+i \Psi)$ である.

$d W / d z=u-i v=q \cdot \exp (-i \theta)$.

であるから式（1）は

$\Omega=\ln \left(V_{3} / q\right)+i \theta$

と表現できる.ここに， $u, v$ : 物理面上の $x, y$ 軸方 向の流速成分, $q=\left(u^{2}+v^{2}\right)^{1 / 2}, \theta=\arctan (v / u)$. したがっ て，対象とする流れ場の流速べクトルの場 $(q, \theta)$ を 与えれば，対応するホドグラフ面（ $\Omega$-面）を得ること ができる．次に，媒介面としてと一面を考え，Schwarz・ Christoffel の変換（以降，S.C. 変換と称する）を用い て，ホドグラフ面の内部をと-面の上半分の領域に等角 写像すると次の写像関数が得られる.

$$
\Omega=f(\zeta) \cdots
$$

一方, 複素速度ポテンシャル $W$ の内部を式 (4) と 同一の媒介面の上半分の領域に S. C. 変換すると次の関 係が得られる.

$d W / d \zeta=g(\zeta)$

式 (1), (4) より

$$
d z / d W=\exp \{f(\zeta)\} / V_{3}=h(\zeta)
$$

また,

$$
d z / d \zeta=d z / d W \cdot d W / d \zeta
$$

であるから，式（5)，（6）を式（7）に代入して

$d z / d \zeta=h(\zeta) g(\zeta)$

が得られる. 物理面 $z$ と媒介面 $\zeta$ の関係はこれを積分 して次式より得られる.

$z=\int h(\zeta) g(\zeta) d \zeta$

$W$-面の各流線（ $\Psi=$ const. ） に対応する $\zeta$-面上の值 がわかれば，式（9）から対応する物理面上の流線を求 めることができる，通常，自由流線は $\zeta$ 一面の実軸に対 応しているが, それ以外の流線は $\zeta$-面の内部の点に対 応するので，その場合には式（9）の積分は複素平面内
で実行することになる．次節においては，以上の理論を 合流部に適用する.

\section{3. ホドグラフ法の合流部への適用}

本研究では直線水路に支流がある角度で合流する Fig. 1 のような流れ場を取り扱う。ここに， $\alpha$ : 合流角, $B$ : 水路幅, $V:$ 流速, $H:$ 死水域幅, $b$ : 有効水路幅, $L$ : 死水域長である. 添字の $1 ， 2 ， 3$ はそれぞれ合流前 の本流，支流，および合流後の流れに関する值を示す. $\mathrm{FE}_{1}$ で示す破線の部分が自由流線であり，ここでは Kirchhoff のモデルに従い，この流線上で流速が一定 (= $\left.V_{3}\right)$ と仮定した. $\mathrm{FG}_{1}$ の区間は死水域の発達域であり, 点 $G_{1}$ において死水域幅が最大となる. 有効水路幅 $b$ は 水路幅 $B_{3}$ から死水域幅 $H$ を差し引いて求められる. 死水域の長さ $L$ は死水域形状が近似的に $\mathrm{GG}_{1}$ 断面を中 心とする対称形と仮定すれば， $L=2 \mathrm{FG}$ で与えられる.

ホドグラフ法では壁面を 1 つの流線とみなすので，本 流・支流の壁面 $\mathrm{C}_{1} \mathrm{~A}$ および $\mathrm{D}_{1} \mathrm{~A}$ で同一の流れ関数值を 有する流線は, 壁面上のよどみ点 $\mathrm{S}$ を端点として水路 内部へ貫入する (Fig. 2).この流線（ここでは境界流線 とよぶ)は水路内部では本流と支流の流れの境界を示す.

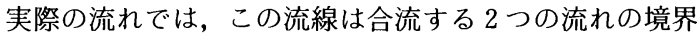
に生じる自由せん断層的な流れの中心位置に対応すると 考えられる. 合流部の境界流線は常によどみ点が点 $\mathrm{A}$

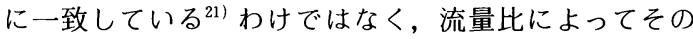
位置が変わってくる．本研究ではよどみ点 $\mathrm{S}$ の位置に よって次の 3 つのケースに分類する ${ }^{20)}$.

（1）よどみ点が合流部の頂点 A に一致する場合 (CASE A)

（2）上どみ点が本流壁上にある場合 (CASE B)

（３）よどみ点が支流壁上にある場合（CASE C)

CASE B は支流からの流れの流入量が相対的に多い

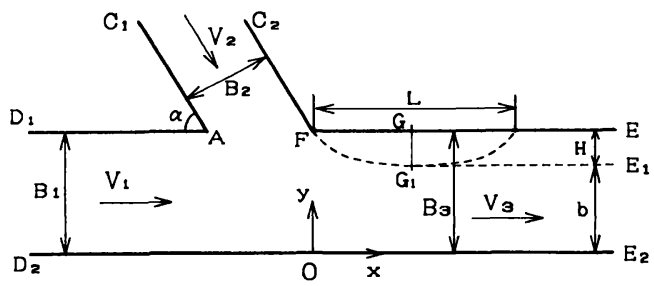

Fig. 1 Definition sketch.

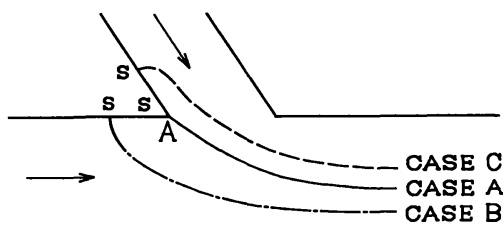

Fig. 2 Boundary streamlines for each case. 
場合，CASE C は支流からの流れの流入量が相対的に 少ない場合, CASE A はその中間の場合に生じると考 えられる.この様子を模式的に示したのが Fig. 2 である. 流れをポテンシャル流として取り扱う場合, CASE B, Cでは点 A の角を回る流れが生じ，ポテンシャル流の 性質から点 A における流速が無限大となる矛盾が生じ る. 点 $\mathrm{A}$ での水路形状に丸みをつければ流速值を有限 の值とすることは可能であるが，ホドグラフ法では流速 ベクトル場の方を先に与えるため，この物理形状をあら かじめ決めておくことができない。したがって, 本研究 では CASE B , C の場合には, 点 A という特異点が流 速の場に及ぼす影響範囲は小さいとし，あえて点 Aで の無限大流速值を許すものとして解析を行う. 以下, 各 ケースについての解析法を示す.

\section{(1) CASE A}

写像面（ $\Omega$-面， $W$-面，および $\zeta$-面）を Figs. 3, 4, および Fig. 5 に示す. $\Omega$-面の内部を $\zeta$-面の上半分の領 域に写像する写像関数は S. C. 変換より得られた

$$
\frac{d \Omega}{d \zeta}=\frac{K_{1}}{\sqrt{\zeta^{2}-\zeta}}
$$

を積分し, 点 $\mathrm{E}(\Omega=0, \zeta=0)$ 之点 $\mathrm{F}(\Omega=-\alpha i, \zeta=$

1)の条件を用いて, 次のように得られる.

$$
\Omega=\frac{2 \alpha}{\pi} \log (\sqrt{\zeta-1}+\sqrt{\zeta})-\alpha i
$$

点 $\mathrm{C}$ ，および点 $\mathrm{D}$ の条件からは以下の関係が得られる.

$$
\begin{aligned}
& c=\left(p^{2}+1\right)^{2} /\left(4 p^{2}\right) \cdots \\
& d=\left(s^{2}-1\right)^{2} /\left(4 s^{2}\right) \cdots \\
& p=\left(\frac{B_{r} B_{3}}{b Q_{r}}\right)^{\pi / 2 \alpha} \ldots \ldots \\
& s=\left\{\frac{B_{1}}{b\left(1-Q_{r}\right)}\right\}^{\pi / 2 \alpha}
\end{aligned}
$$

ここに, $B_{r}:$ 水路幅比 $\left(=B_{2} / B_{3}\right), Q_{r}:$ 流量比 $\left(=Q_{2} / Q_{3}\right)$ である.

$W$-面の内部を $\zeta$-面の上半分に写像する写像関数は S. C. 変換より

$$
\frac{d W}{d \zeta}=\frac{G_{1}}{\zeta(\zeta-c)(\zeta+d)}
$$

で与えられ, 積分して次式が得られる.

$$
\begin{aligned}
W= & Q_{3} / \pi\left\{-\log \zeta+Q_{r} \log (\zeta-c)\right. \\
& \left.+\left(1-Q_{r}\right) \log (\zeta+d)\right\} \ldots \ldots \ldots \ldots \ldots \ldots
\end{aligned}
$$

点 $\mathrm{C}$ ，および点 $\mathrm{D}$ に関する条件からは次の関係が得ら れる.

$$
Q_{r}=\frac{d}{c+d}
$$

式（9）に対応する写像関係は次式のようになる.

$z=\int F_{1}(\zeta) d \zeta$

ここに,

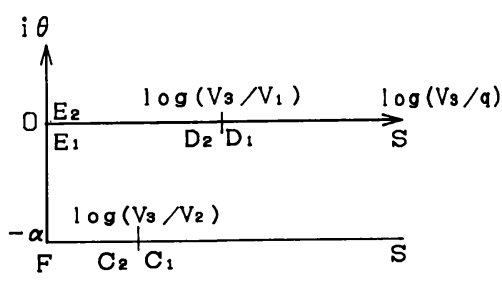

Fig. $3 \Omega$-plane (CASE A).

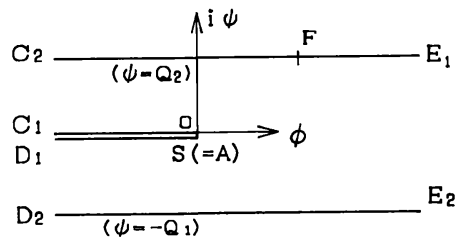

Fig. $4 W$-plane (CASE A).

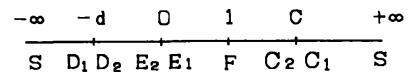

Fig. $5 \zeta$-plane (CASE A).

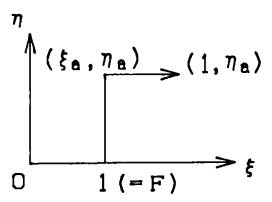

Fig. 6 Path of integration.

$$
F_{1}(\zeta)=\frac{b}{\pi} \exp \Omega\left(-\frac{1}{\zeta}+\frac{Q_{r}}{\zeta-c}+\frac{1-Q_{r}}{\zeta+d}\right)
$$

である、ただし， $Q_{3}=\pi$ とおいた。式 $(20)$ を

$$
F_{1}(\zeta)=F_{R}(\zeta)+i \cdot F_{l}(\zeta)
$$

のように実数部と虚数部とに分割し, 点 $\mathrm{F}(\zeta=1, z=$ $\left.z_{F}=B_{3} i\right)$ を端点とする Fig. 6 のような積分経路をたよ゙ れば, $\zeta$-面上の点 $\left(\xi_{a}, \eta_{a}\right)$ に対応する物理面上の点 $\left(x_{a}\right.$, $\left.y_{a}\right)$ は次のように表わせる.

$$
\begin{aligned}
& x_{a}=\int_{1}^{s_{a}} F_{R}\left(\xi+i \eta_{a}\right) d \xi-\int_{0}^{\eta_{a}} F_{I}(1+i \eta) d \eta \cdots \cdots \\
& y_{a}=\int_{1}^{s_{a}} F_{I}\left(\xi+i \eta_{a}\right) d \xi+\int_{0}^{\eta_{a}} F_{R}(1+i \eta) d \eta+B_{3}
\end{aligned}
$$

自由流線 $\left(x_{s}, y_{s}\right)$ は媒介面上では実軸上の $0<\xi<1$ に対応しているので，式（22），(23）より次式が得られ る.

$$
\begin{aligned}
& x_{s}=-\int_{\xi_{s}}^{1} F_{R}(\xi) d \xi \\
& y_{s}=B_{3}-\int_{s_{s}}^{1} F_{l}(\xi) d \xi
\end{aligned}
$$

式 (24)，(25) は 
$\beta_{1}=\frac{2 \alpha}{\pi} \arctan \sqrt{\frac{1-\xi}{\xi}}-\alpha$

とおけば次式のように表わされる.

$x_{s}=-\frac{b}{\pi} \int_{s_{s}}^{1}\left(-\frac{1}{\xi}+\frac{Q_{r}}{\xi-c}+\frac{1-Q_{r}}{\xi+d}\right) \cos \beta_{1} d \xi$

$y_{s}=-\frac{b}{\pi} \int_{\xi s}^{1}\left(-\frac{1}{\xi}+\frac{Q_{r}}{\xi-c}+\frac{1-Q_{r}}{\xi+d}\right) \sin \beta_{1} d \xi+B_{3}$

式 $(28)$ で $\xi_{s} \rightarrow+0$ とおけば, $y_{s} \rightarrow b$ となるので有効 水路幅 $b$ は,

$$
b=\frac{\pi}{1+\frac{1}{\pi} \int_{0}^{1}\left(-\frac{1}{\xi}+\frac{Q_{r}}{\xi-c}+\frac{1-Q_{r}}{\xi+d}\right) \sin \beta_{1} d \xi}
$$

と表わすことができる，ただし，ここでは $B_{3}=\pi$ とお いた. 写像係数 $c, d$ は式 $(12) \sim(15)$ より $b$ の関数 である.したがって， $b$ の值は与えられた水路形状のパ ラメーター $\left(\alpha, B_{r}\right)$, および水理量のパラメーター $\left(Q_{r}\right)$ に対して式（12)～(15)，および式（29）より逐次代入 法で求めることができる，ただし，W-面と $\zeta$-面の写像 関係より, 流量比と写像係数の間には水路形状とは無関 係に式（18）の関係が成立している，よって，式（18） を同時に満たすような写像係数は与えられた水路形状に

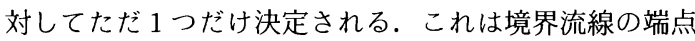
であるよどみ点 $\mathrm{S}$ が合流部の頂点 $\mathrm{A}$ に厳密に一致する

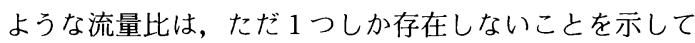
いる.ここでは，このような流量比を限界流量比として $Q_{r c}$ で表わし, 限界流量比を用いて得られる解を厳密解 とよぶこととする. 合流角，および水路幅比に対する写 像係数之 $Q_{r c}$ の值を Table 1 に示す. $b / B_{3}$ は縮流係数 に相当する値である.

一方, 式 (17) に示す $W$-面から $\zeta$-面への写像関数 は $\zeta$-面の実軸上の原点 $(\xi=0)$ に強さ $2 Q_{3}$ の吸い込み, $\xi=-d, c$ にそれぞれ強さ $2 Q_{1}, 2 Q_{2}$ の涌き出しを置 いた場合の複素速度ポテンシャルとも解釈できる．湧き 出し，吸い込みのそれぞれの強さを変えれば，流量比の 異なる合流部の流れを表わすことができる。ただし，流 量比が限界流量比と異なる場合は, 厳密には $B_{1}=B_{3}$ の 水路ではなく, Fig.7に模式的に示すように, $Q_{r}>Q_{r c}$ の場合は $B_{3}>B_{1}, Q_{r}<Q_{r c}$ の場合は $B_{3}<B_{1}$ となるよ うな水路に対する流線を求めていることになる．実用的 な立場からみれば, $B_{1} \approx B_{3}$ とみなせるような流量比の 範囲においてなら，限界流量比以外の流量比を用いても 差し支えないと考える。ここでは，このような解を簡略 解とよぶことにする. $B_{r}=0.5$ ，および 1.0 の場合につ いて式 (18) の右辺と流量比の関係を示したのが Fig. 8 である. 図中の交点が $Q_{r c}$ を示す. 合流角が小さいほ
Table 1 Mapping coefficients for critical discharge ratio $Q_{r c}$. $\alpha=30^{\circ}$

\begin{tabular}{ccccc}
\hline $\mathrm{B}_{2} / \mathrm{B}_{3}$ & $\mathrm{c}$ & $\mathrm{d}$ & $\mathrm{b} / \mathrm{B}_{3}$ & $\mathrm{Qrc}$ \\
\hline 0.1 & 5.52374 & 0.47604 & 0.8656 & 0.0680 \\
0.2 & 7.98669 & 1.24955 & 0.8391 & 0.1353 \\
0.3 & 9.95210 & 2.45740 & 0.8271 & 0.1980 \\
0.4 & 12.5586 & 4.30824 & 0.8209 & 0.2554 \\
0.5 & 15.9845 & 7.09713 & 0.8176 & 0.3075 \\
0.6 & 20.4514 & 11.2312 & 0.8158 & 0.3545 \\
0.7 & 26.2289 & 17.2608 & 0.8148 & 0.3969 \\
0.8 & 33.6434 & 25.9166 & 0.8142 & 0.4351 \\
0.9 & 43.0825 & 38.1555 & 0.8139 & 0.4697 \\
1.0 & 55.0074 & 55.2051 & 0.8138 & 0.5009 \\
\hline
\end{tabular}

$\alpha=60^{\circ}$

\begin{tabular}{ccccc}
\hline $\mathrm{B}_{2} / \mathrm{B}_{3}$ & $\mathrm{c}$ & $\mathrm{d}$ & $\mathrm{b} / \mathrm{B}_{3}$ & $\mathrm{Qrc}$ \\
\hline 0.1 & 2.70483 & 0.17214 & 0.8126 & 0.0598 \\
0.2 & 2.89350 & 0.40872 & 0.7639 & 0.1238 \\
0.3 & 3.11887 & 0.71592 & 0.7367 & 0.1867 \\
0.4 & 3.38212 & 1.10707 & 0.7199 & 0.2466 \\
0.5 & 3.68540 & 1.59920 & 0.7089 & 0.3026 \\
0.6 & 4.03145 & 2.21277 & 0.7016 & 0.3544 \\
0.7 & 4.42350 & 2.97170 & 0.6967 & 0.4018 \\
0.8 & 4.86508 & 3.90335 & 0.6935 & 0.4452 \\
0.9 & 5.35945 & 5.03967 & 0.6913 & 0.4846 \\
1.0 & 5.91057 & 6.41619 & 0.6899 & 0.5205 \\
\hline
\end{tabular}

$\alpha=90^{\circ}$

\begin{tabular}{ccccc}
\hline $\mathrm{B}_{2} / \mathrm{B}_{3}$ & $\mathrm{c}$ & $\mathrm{d}$ & $\mathrm{b} / \mathrm{B}_{3}$ & $\mathrm{Qrc}$ \\
\hline $\mathrm{c} .1$ & 1.67529 & 0.10963 & 0.7696 & 0.0615 \\
0.2 & 1.73100 & 0.26049 & 0.7045 & 0.1308 \\
0.3 & 1.79782 & 0.45373 & 0.6664 & 0.2015 \\
0.4 & 1.87548 & 0.69506 & 0.6418 & 0.2704 \\
0.5 & 1.96408 & 0.99186 & 0.6252 & 0.3356 \\
0.6 & 2.06350 & 1.35321 & 0.6139 & 0.3561 \\
0.7 & 2.17399 & 1.78935 & 0.6051 & 0.4515 \\
0.8 & 2.29572 & 2.31195 & 0.6009 & 0.5018 \\
0.9 & 2.42885 & 2.93401 & 0.5974 & 0.5471 \\
1.0 & 2.57354 & 3.67005 & 0.5878 & 0.5878 \\
\hline
\end{tabular}

ど流量比の変化に伴う $Q_{r c}$ からのずれが著しいことが わかる. 池田ら ${ }^{19)}$ は Fig. 3 とは異なるホドグラフ面を 用い, 直角合流の場合について流線解析を行っているが, 本研究の簡略解は, 池田らの方法を任意の合流角にまで 拡張したものといえる. 池田らの解析結果は本研究の簡 略解で $\alpha=90^{\circ}$ とおいて得られる結果と一致した.

境界流線は $W$-面上では $\Psi=0$ の流線（Fig.4）に対 応する. 境界流線の軌跡は, 式 (17) より $\Psi=0$ に対応 する -面上の值を求め, 式 (22)，(23）により物理面 の値に変換して求める.

\section{(2) CASE B}

合流部の頂点 A で無限大の流速を許せば，ホドグラ フ面はFig. 9 のようになる。W-面はCASE A と同し 形だが点 $\mathrm{A}$ は $\mathrm{C}_{1} \mathrm{~S}$ 上へ移動する。 Fig. 9 の内部を Fig. 10 の媒介面の上半分の領域に写像する写像関数は S. C. 変換より得られる

$$
\frac{d \Omega}{d \zeta}=\frac{K_{2}(\xi-c)}{(\zeta-a) \sqrt{\zeta^{2}-\zeta}}
$$

を積分し, 点 $\mathrm{E}(\Omega=0, \quad \zeta=0)$ と点 $\mathrm{F}(\Omega=-\alpha i, \quad \zeta=$ 1)の条件を用いて次のように得られる. 
$\Omega=-2 i\left[\gamma+\frac{\pi-\alpha}{\pi} \arctan \left\{-\sqrt{\frac{a-1}{a}} \tan \gamma\right\}\right]$

ここに,

$$
\tan \gamma=\sqrt{\frac{\zeta}{1-\zeta}}
$$

である。写像係数間の関係は点 A，C，Dについての条 件よりそれぞれ次のように得られる.

$$
\frac{a-c}{\sqrt{a^{2}-a}}=\frac{\pi-\alpha}{\pi}
$$

$\frac{B_{2}}{b Q_{r}}=\left\{\frac{\sqrt{c(a-1)}-\sqrt{a(c-1)}}{\sqrt{c(a-1)}+\sqrt{a(c-1)}}\right\}^{\frac{\pi-a}{\pi}}$

$$
\times\left(\frac{\sqrt{c}+\sqrt{c-1}}{\sqrt{c}-\sqrt{c-1}}\right)
$$

$$
\frac{B_{1}}{b\left(1-Q_{r}\right)}=\left\{\frac{\sqrt{a(d+1)}-\sqrt{d(a-1)}}{\sqrt{a(d+1)}+\sqrt{d(a-1)}}\right\}^{\frac{\pi-\alpha}{\pi}}
$$

$$
\times\left(\frac{\sqrt{d+1}+\sqrt{d}}{\sqrt{d+1}-\sqrt{d}}\right)
$$

有効水路幅 $b$ は CASE A と同様に次式で表わされる.

$$
b=\frac{\pi}{1+\frac{1}{\pi} \int_{0}^{1}\left(-\frac{1}{\xi}+\frac{Q_{r}}{\xi-c}+\frac{1-Q_{r}}{\xi+d}\right) \sin \beta_{2} d \xi}
$$

ここに,

$$
\begin{aligned}
& \beta_{2}=2 \arctan \sqrt{\frac{1-\xi}{\xi}+\frac{\pi-\alpha}{\pi}} \gamma_{2}-\pi \\
& \gamma_{2}=\arctan \left[\frac{2 \sqrt{\left(a^{2}-a\right)\left(\xi-\xi^{2}\right)}}{-2 a \xi+\xi+a}\right] \cdots
\end{aligned}
$$

である. 写像係数 $a, c, d$ の值は式 (33) (38) より 求められる.

CASE B の場合にも CASE A と同様, 写像係数 $c$, $d$ と流量比との間には式（18）が成立しているが，ここ では CASE A における簡略解と同様の取り扱いのみを 行う。ここで得られる結果は, 流量比が限界流量比 $Q_{r c}$ よりも大きい範囲において適用できる.

\section{(3) CASE C}

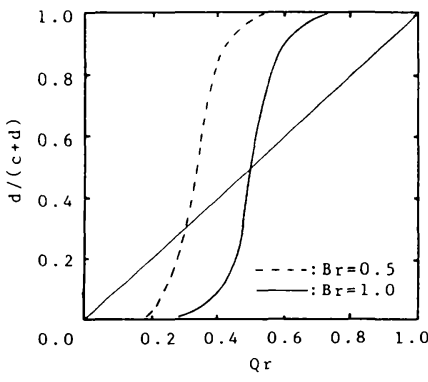

$\alpha=30^{\circ}$

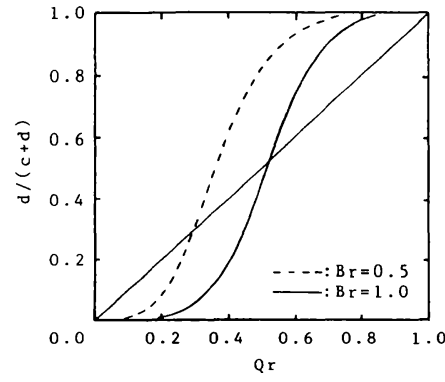

$\alpha=60^{\circ}$

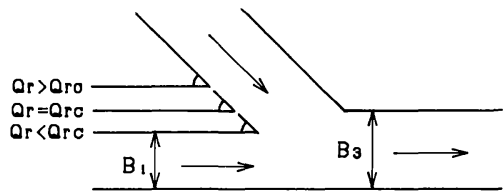

Fig. 7 Effects of discharge ratios.

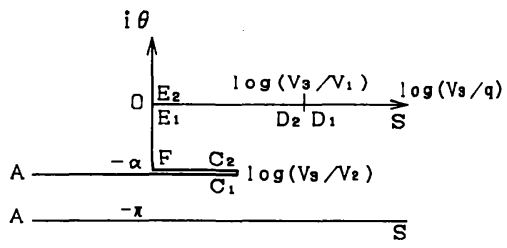

Fig. $9 \Omega$-plane (CASE B).

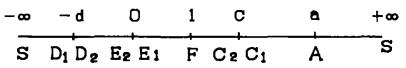

Fig. $10 \zeta$-plane (CASE B).

CASE B と同様, 頂点 A で無限大の流速を許せば, $\Omega$-面, $\zeta$-面はそれぞれ Fig. 11，12 のように表わされる。 $W$-面は CASE B と同じだが，点 $\mathrm{A}$ は $\mathrm{D}_{1} \mathrm{~S}$ 上へ移動す る. $\Omega$-面から $\zeta$-面への変換は,

$$
\frac{d \Omega}{d \zeta}=\frac{K_{3}(\zeta+d)}{(\zeta+a) \sqrt{\zeta^{2}-\zeta}}
$$

を積分し，次のように得られる.

$$
\Omega=-2 i\left[\gamma-\frac{\pi-\alpha}{\pi} \arctan \left\{\sqrt{\frac{a+1}{a}} \tan \gamma\right\}\right]
$$

写像係数間の関係は次のようである.

$$
\begin{aligned}
& \frac{a-d}{\sqrt{a^{2}+a}}=\frac{\pi-\alpha}{\pi} \\
& \frac{B_{2}}{b Q r}=\left\{\frac{\sqrt{c(a+1)}-\sqrt{a(c-1)}}{\sqrt{c(a+1)}+\sqrt{a(c-1)}}\right\}^{\frac{\pi-\alpha}{\pi}} \\
& \times\left(\frac{\sqrt{c}+\sqrt{c-1}}{\sqrt{c}-\sqrt{c-1}}\right)
\end{aligned}
$$

Fig. 8 Comparison between discharge ratio and the value of $d /(c+d)$ for different confluence angles. 


$$
\begin{aligned}
& \frac{B_{1}}{b\left(1-Q_{r}\right)}=\left\{\frac{\sqrt{a(d+1)}-\sqrt{d(a+1)}}{\sqrt{a(d+1)}+\sqrt{d(a+1)}}\right\}^{\frac{\pi-a}{\pi}} \\
& \times\left(\frac{\sqrt{d+1}+\sqrt{d}}{\sqrt{d+1}-\sqrt{d}}\right)
\end{aligned}
$$

有効水路幅は

$$
b=\frac{\pi}{1+\frac{1}{\pi} \int_{0}^{1}\left(-\frac{1}{\xi}+\frac{Q_{r}}{\xi-c}+\frac{1-Q_{r}}{\xi+d}\right) \sin \beta_{3} d \xi}
$$

で表わされる.ここに，

$$
\begin{aligned}
& \beta_{3}=-2 \arctan \sqrt{\frac{1-\xi}{\xi}}+\frac{\pi-\alpha}{\pi} \gamma_{3}-\pi \\
& \gamma_{3}=\arctan \left[\frac{2 \sqrt{\left(a^{2}+a\right)\left(\xi-\xi^{2}\right)}}{2 a \xi+\xi-a}\right] \ldots \ldots
\end{aligned}
$$

である。

CASE C の結果は限界流量比 $Q_{r c}$ よりも小さい流量 比の範囲に対して適用できる。

\section{4. 実験}

本理論を検証するために，河床勾配を水平に設置した アクリル製水路（本川長 $10 \mathrm{~m}$, 支川長 $2.5 \mathrm{~m}$, 本川幅 $30 \mathrm{~cm}$, 支川幅 $10,20 \mathrm{~cm}$, 合流角 $30^{\circ}, 60^{\circ}, 90^{\circ}$ ) を用 いて死水域形状や流速分布等を測定した。死水域形状等 の測定はおがくずとタフトを用いた可視化，流速測定は 直径 $3 \mathrm{~mm}$ の小型正逆プロペラ流速計により行った. 水 理条件は全流量 $0.005 \mathrm{~m}^{3} / \mathrm{s}$, 流量比 $Q_{r}=0.1 \sim 0.6$, 合 流後の水路のフルード数 $F_{r_{3}}=0.1 \sim 0.57$ である. 合流 前後の流れはいずれも常流状態を保つようにした。これ は本理論は平面ポテンシャル解析であり, 水深変化の影 響を表わせないため水理条件を低フルード数の範囲にお さえる必要があるためである.

\section{5. 計算結果}

\section{(1) 写 像係数}

CASE A, CASE B および CASE C の写像係数を

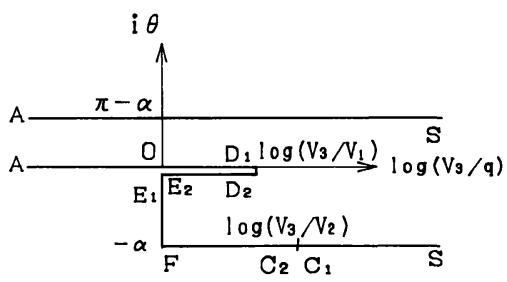

Fig. $11 \Omega$-plane (CASE C).

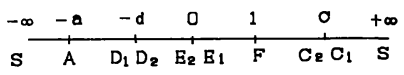

Fig. $12 \zeta$-plane (CASE C).

Fig. 13 に示す.ここでは各ケースの簡略解に対する写 像係数を広範囲の流量比に対して示した。

\section{（2）ケースによる違い}

流量比が限界流量比 $Q_{r c}$ より小さい場合は式 (36), 大きい場合に式（44）を用いて得られた有効水路幅と流 量比，および合流角の関係を Fig. 14 に示す. 破線は CASE A における簡略解をすべての流量比の範囲に適 用して得られた結果である. これより有効水路幅の算定 に関しては，ホドグラフ面の選択の違いによる差はあま りないことがわかる.

\section{（3）有効水路幅と運動量比の関係}

Fig. 15 に一定の流量比のもとで水路幅比 $B_{r}$ を変化さ せたときの有効水路幅を示す。これより，合流部の流れ は流量比だけでは規定できず，水路幅比にもある程度， 依存していることがわかる. そこで, 流量比のかわりに 式（47）で定義する運動量比を用いて $B_{r}=0.1 \sim 1.0$, $Q_{r}=0.1 \sim 0.8$ の範囲の理論值をプロットしたのが Fig. 16 である.

$$
M_{r}=\frac{B_{2} V_{2}^{2}}{B_{3} V_{3}^{2}}=\frac{Q_{r}^{2}}{B_{r}}
$$

有効水路幅の変化は, 近似的には図中の実線で表わす ことができると考えられる。このようにして得られた理 論曲線と実験值を比較した結果を Fig. 17 に示す. 図に

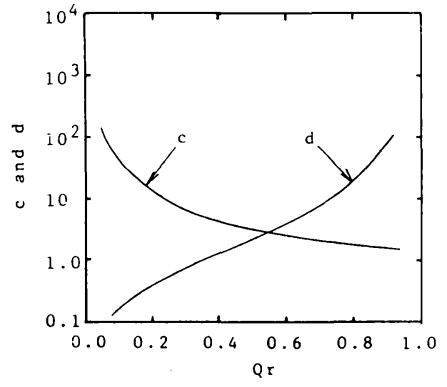

CASE A

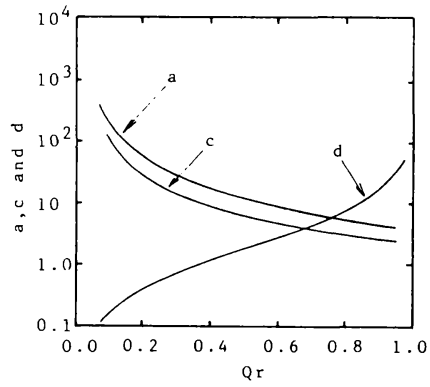

CASE B

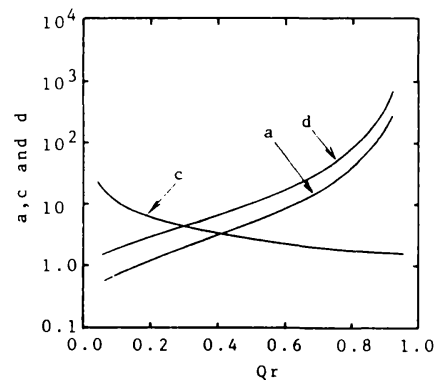

CASE $C$

Fig. 13 Relationship of the mapping coefficients to discharge ratios $\left(\alpha=90^{\circ}, B_{r}=1.0\right)$. 


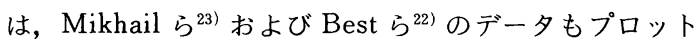
した。これより，合流角が大きい場合は実験值との対応 は比較的よいが, 合流角が小さくなると理論值は死水域 幅を過大評価するようになることがわかる.

\section{（4）死水域の長さ}

自由流線を死水域幅 $H$ で無次元表示した例を Fig. 18 に示す．自由流線は合流角が大きいほどわずかに曲率が 大きくなっているが，いずれの場合も死水域幅の約 4.0 倍の距離でほぼ最大值に到達していることがわかる。こ の無次元形状は流量比や水路幅比を変えてもあまり変わ らず，ほぼ相似形を保つ。したがって，Fig.1で示した ように死水域形状の対称性を仮定すれば，死水域長 $L$ は,

$$
L \approx 8 H
$$

で推定できる. すなわち, 死水域の形状係数 $H / L$ が普 遍的に 0.13 程度であることが推定できる。この値を実 験值と比較したのが Fig. 19 である. 式（48）は実験值 の平均值にほぼ対応していることがわかる.

\section{（5）流速分布との比較}

Fig. 20 と Fig. 21 に合流角が $30^{\circ}$ と $90^{\circ}$ の場合の流下 方向の平均流速分布，および乱れ強度分布を示す．流量 比は 0.4 , フルード数は 0.48 である. $30^{\circ}$ の場合は水面 近傍の値，剝離せん断層が十分に発達する $90^{\circ}$ の場合は 流れの中層部および底層部における值も示した。 $H_{3}$ は 合流点より $4 B_{3}$ だけ下流の断面における平均水深， $U_{m}$ はその断面における断面平均流速である．図には本理論 で得られた自由流線および境界流線，ならびに表面流の 可視化により得られた死水域と境界流線む示した。

Fig. 21 において, 剝離せん断層の存在により影響を受 けると思われる平均流速分布の勾配急変点や乱れ強度分 布の極大点の位置に注目した場合, 底面近傍 $\left(z / H_{3}=\right.$ $0.1)$ を除けば, 水深方向への著しい変化は認められない. したがって, 㓦離せん断層に関する以下の考察について は，水深平均的な流れに対するものと考えてよい.

自由流線はいずれの場合も横断方向の平均流速勾配の 急変点にほぼ対応している。これは, 自由流線が剝離せ
ん断層の中心というょりも外縁付近の位置に対応してい ることを示している．また，この位置は乱れ強度分布の 勾配が最大となる点にほぼ一致していることがわかる。

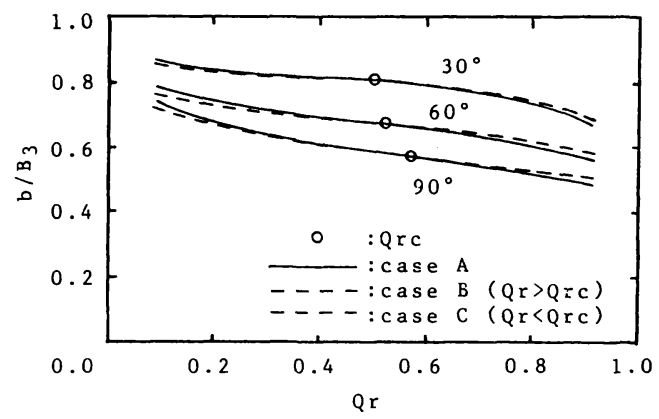

Fig. 14 Relationship between discharge ratio and effective channel width.

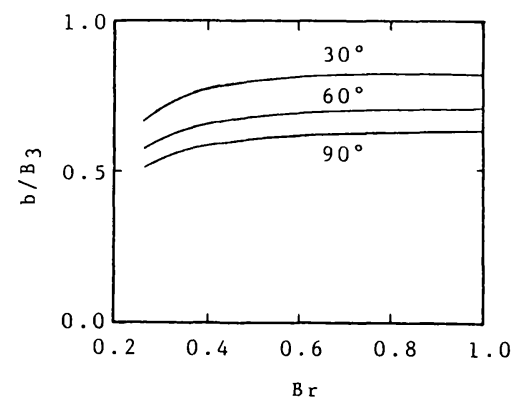

Fig. 15 Effects of channel width ratio $\left(Q_{r}=0.4\right)$.

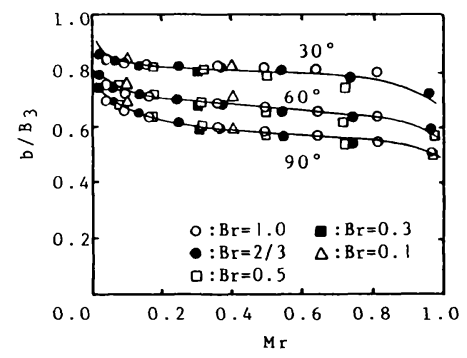

Fig. 16 Variation of effective channel width ratio to momentum ratio.

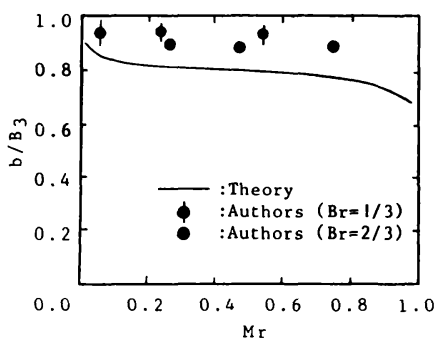

$\alpha=30^{\circ}$

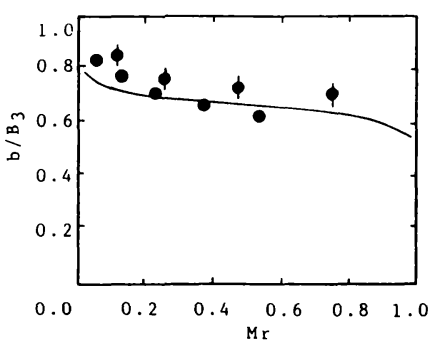

$\alpha=60^{\circ}$

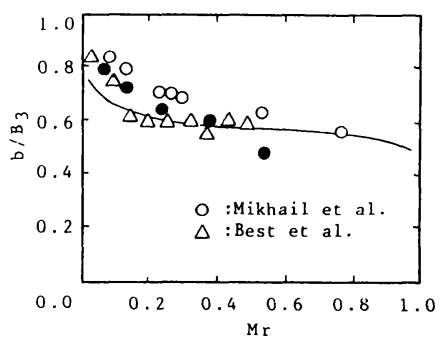

$\alpha=90^{\circ}$

Fig. 17 Comparison between computed and observed effective channel widths. 
境界流線については，流速分布形との直接的な関係は明 確ではないが, 可視化により得られたデータとの対応は 良好であるといえる.

死水域については, 合流角が大きい場合, 死水域幅が 最大となる地点までは剝離せん断層と分離流線はほぼ一 致しているため, 自由流線により死水域幅はうまく予測 されている. 合流角が小さい場合は, 自由流線は剝離せ ん断層とはうまく対応しているが, 分離流線は剝離せん 断層が十分発達する前に側壁に再付着するため, 死水域 規模は自由流線によって予測されたものよりは小規模と なっている.

流量比が異なる場合の各流線の比較を行ったのが Fig. 22 および Fig. 23 である. Fig. 22 は CASE A, Fig. 23 は CASE C の理論式を用いて流線の計算を行っ ている. どちらのケ一スも境界流線の端点であるよどみ 点の位置がほぼ実験值に一致していることがわかる．境 界流線そのものの形状は多少の誤差はあるものの, 実測 值とほぼ一致している. また, 特に流量比が 0.6 の場合, 乱れ強度分布には第 2 の極大值が明確に現われている

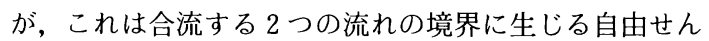
断層的な流れによるものと思われる.この位置は, ほぼ 境界流線に一致している. 空間的には境界流線の近傍で 二次流が発達していると考えられ, その意味で境界流線 の予測は死水域に次いで重要な問題と考えられる.

\section{6. 結 論}

本研究ではホドグラフ法というある意味で古典的な手 法を用いて合流部の流線の解析を行った.この手法の

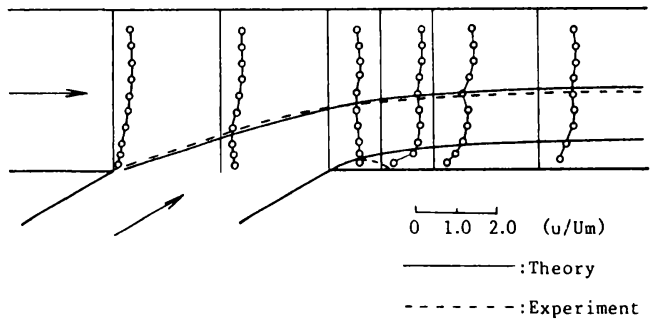

(a) Mean velocity

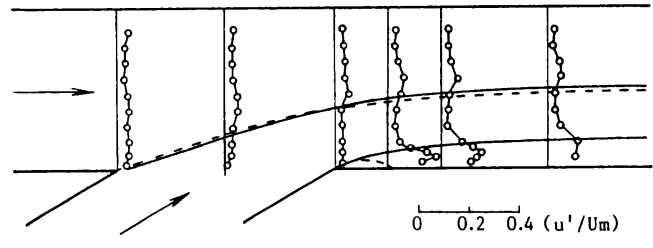

(b) Turbulent intensity

Fig. 20 Streamlines and velocity distributions ( $\alpha=30^{\circ}, Q_{r}=$ $\left.0.4, B_{r}=2 / 3, F_{r_{3}}=0.48, z / H_{3}=0.9\right)$.
魅力は補正係数などをまったく用いずに解析的に流線が 得られるという点であるが, 理論解析の結果, すべての 写像面の関係を満足し純粋に解析的に得られるのは, 合 流部におけるよどみ点の位置に関する考察から得られる 限界流量比を用いた場合のみであることがわかった。こ

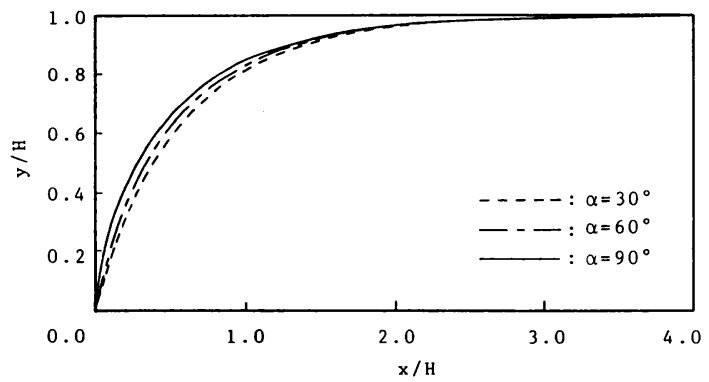

Fig. 18 Shapes of free streamlines $\left(Q_{r}=0.3, B_{r}=1.0\right)$.

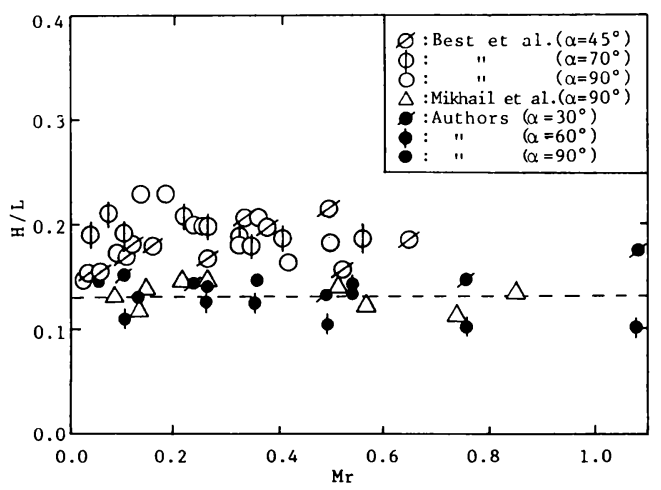

Fig. 19 Width of dead water zone.

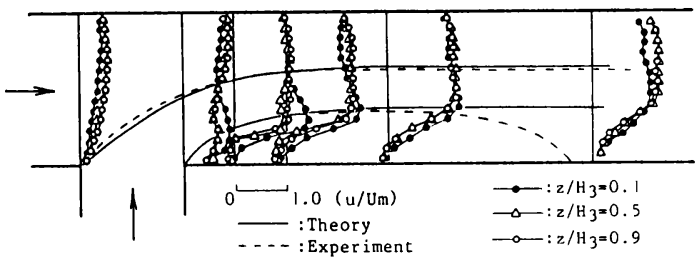

(a) Mean velocity

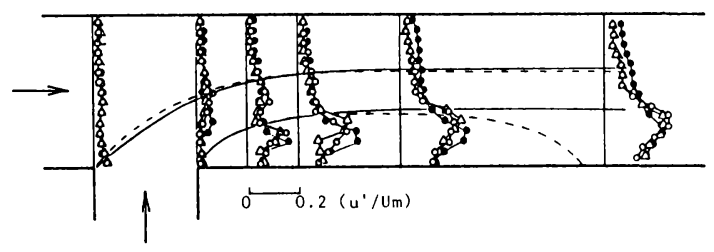

(b) Turbulence intensity

Fig. 21 Streamlines and velocity distributions $\left(\alpha=90^{\circ}, Q_{r}=\right.$ $0.4, \quad B_{r}=2 / 3, F_{r_{3}}=0.48$ ). 


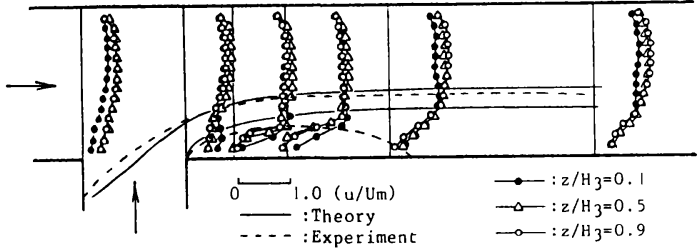

(a) Mean velocity

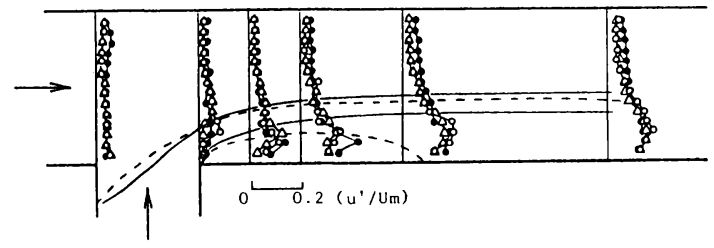

(b) Turbulence intensity

Fig. 22 Streamlines and velocity distributions $\left(\alpha=90^{\circ}, Q_{r}=\right.$ $\left.0.2, \quad B_{r}=2 / 3, \quad F_{r_{3}}=0.48\right)$.

の点がホドグラフ法の限界であるとも考えられる. しか しながら，少なくとも簡略解を用いれば，剝離せん断層 に対応する流線が得られることがわかった，また，自由 せん断層に対応する境界流線についても実験值と比較し てほぼ妥当な結果が得られることがわかった．剝離せん 断層の生成に伴って形成される死水域の幅に関しては, 合流角が小さい場合には過大評価となったが, 合流角が 大きい場合には実験值と比べてほぼ妥当な結果を得るこ とができた．死水域の形状係数に関しても，理論的に実 験值を裏付けることができた。

ただし，本解析は平面ポテンシャルによる解析である ため, 流れの連続条件等を考慮すると, 厳密に対象とな る流れは水深変化の小さい低フルード数の流れに限られ てくる. しかしながら, 本研究で示した実験範囲および 結果から判断すると合流前後の流れが常流の範囲であれ ば，近似的に本理論は適用可能であると考えられる.

\section{参 考 文 献}

1）板倉忠興：河川合流点における流れの機構の研究，第 16 回水理講演会講演集, pp. $7 \sim 12,1972$.

2）神田 徹・山崎 篤：開水路合流部の流れの水理学的特 性, 建設工学研究所報告, 第 19 号, pp. $137 \sim 153$, 1977.

3）神田 徹・桑田明仁 : 都市河川網における洪水追跡に関 する二, 三の検討, 第 22 回水理講演会論文集, pp. 245 $\sim 252,1978$.

4) Taylor, E.H. : Flow Characteristics at rectangular open-channel junctions, Trans. ASCE, Vol.109, pp. 893 903, 1944.

5）室田 明- 多田博登：開水路合流部の水面形計算接続法 に関する研究, 第 25 回水理講演会論文集, pp. 327 332,

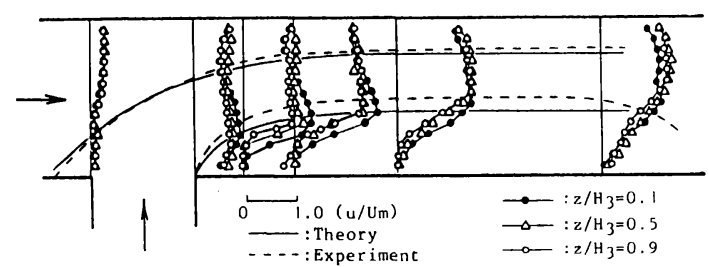

(a) Mean velocity

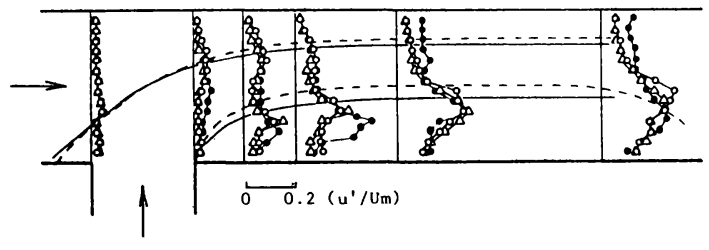

(b) Turbulence intensity

Fig. 23 Streamlines and velocity distributions ( $\alpha=90^{\circ}, Q_{r}=$ $\left.0.6, \quad B_{r}=2 / 3, \quad F_{r_{3}}=0.48\right)$.

1981.

6) Lin, J. D. and Soong, H. K. : Junction Losses in open channel flows, Water Resour. Res., Vol.15, No.2, pp. 414 418, 1979

7）水島敏治・板倉忠興・岸 力：乱流モデルによる開水 路合流部の数值計算, 土木学会第 38 回年次学術講演会講 演概要集, 第 2 部, pp. 357 358, 1983.

8）富所五郎·吉田宏司：合流部の流れの数值計算法, 土木 学会中部支部研究発表会講演概要集, pp. 212 213, 1983.

9）玉井信行・上田 悟：乱流モデルによる河川合流部の流 れの予測, 第 31 回水理講演会論文集, pp. 437 442, 1987.

10) McGuirk, J. J. and Rodi, W. : A depth-averaged mathematical model for the near field of side discharges into open-channel flow, J. Fluid Mech., Vol.86, pp.761 $781,1978$.

11) Komura, S. : River-bed variations at confluences, Proc. of International Symposium on river mechanics, Vol. 1, pp. 773 784, 1973.

12) Mosley, M.P. : An experimental study of channel confluences, J. Geol., Vol. 84, pp. 535 562, 1976.

13) Ashmore, P. and Parker, G. : Confluence scour in coarse braided streams, Water Resour. Res., Vol.19, No. 2, pp. 392 402, 1983.

14）藤田一郎・河村三郎：動的平衡状態における合流部の河 床形状, 土木学会第 41 回年次学術講演会講演概要集, 第 2 部, pp. 395 396, 1986.

15）藤田一郎・河村三郎：移動床合流部に関する実験的研究, 土木学会中部支部研究発表会講演概要集, pp. 126 127, 1985

16）谷一郎 編: 流体力学の進歩 境界層, 丸善, 1984.

17) Good, M.C. and Joubert, P.N. : The form drag of two-dimensional bluff plates immersed in turbulent 
boundary layers, JFM, Vol. 31, pp. 547 582, 1968.

18) Webber, N. B. and Greated, C.A. : An investigation of flow behavior at the junction of rectangular channels, Proc. of the Institution of Civil Engineers, July, pp. 321 $\sim 334,1966$.

19）池田隆治・渡辺 喬：直角合流管（ $\mathrm{T}$ 字管）のはく離を 伴う流れの計算, 岩手大学工学部研究報告, 第 19 巻, pp. 23 28, 1966.

20) Modi, P. N., Ariel, P.D. and Dandedar, M. M. : Conformal mapping for channel junction flow, J. Hydraul. Div., Proc. ASCE, Vol. 107, No. HY 12, pp. 1713 -1733, 1981.
21) Fujita, I. and Komura, S. : Application of the free streamline theory to the flow at a confluence, APD. IAHR, pp. 103 120, 1986.

22) Best, J.L. and Reid, I. : Separation zone at openchannel junctions, J. Hydraul. Eng., ASCE, Vol. 110, No. 11, pp. 1588 1594, 1984.

23) Mikhail, R., Chu, V.H. and Savage, S. B. : The reattachment of a two-dimensional turbulent jet in a confined cross flow, Proc. 16 th IAHR Cong., Vol. 3, pp. 414 419, 1975.

（1988.3.25 • 受付） 